\title{
CELESTITE DEPOSITS IN CALIFORNIA AND ARIZONA.
}

\author{
By W. C. Phalen.
}

\section{INTRODUCTION.}

The Geological Survey has received in the last year inquiries by foreign chemists regarding American occurrences of strontium minerals. Many of the domestic occurrences are of minor extent and most of them are of no commercial value at the present time, but as the two deposits here described may prove to be of some future importance, it has been thought worth while to publish some notes on them.

The writer takes this opportunity to acknowledge the courtesies extended by Messrs. H. H. Kerckhoff, T. L. Henderson, and Percy McCabe, president, secretary, and mine superintendent, respectively, of the Avawatz Salt \& Gypsum Co., in assisting in the work and in placing at his disposal a report on the area in which this company's deposits lie, prepared by $J$. O. Lewis under the direction of Harry R. Johnson, which facilitated the field studies. Acknowledgments are also due to Capt. W. D. Conrad and Mr. Lambert Frye, of Gila Bend, Ariz.

\section{SOURCES OF STRONTIUM SALTS.}

The two strontium minerals of commercial importance are celestite $\left(\mathrm{SrSO}_{4}\right)$ and strontianite $\left(\mathrm{SrCO}_{3}\right)$. Strontianite is the more valuable, as by simple treatment with acids it is readily converted into the salts desired for commercial purposes. It is, however, rarer than celestite and therefore has been mined on a comparatively small scale.

Celestite, the strontium sulphate, may contain small quantities of calcium or barium-metallic elements that are isomorphous with strontium and may replace it. Celestite is highly crystalline, has a vitreous luster, inclining to pearly, and usually has a perfect prismatic cleavage. Most of it is white with a faint bluish tinge (to which it owes its name), but some has a reddish tinge. Its specific gravity varies from 3.95 to 3.97 and its hardness from 3 to $3 \frac{1}{2}$, being about that of calcite.

Strontianite, the carbonate of strontium, commonly occurs in crystals and crystalline masses of white to very pale green color, but in 
places it exhibits shades of gray, yellow, and yellowish brown. It is a brittle mineral, with nearly perfect prismatic cleavage and a hardness of 3.5 to 4 . Its high specific gravity, 3.68 to 3.71 , serves as one of the means of identifying it. As in celestite, the strontium may be replaced by more or less barium or calcium.

Celestite and strontianite are readily determined before the blowpipe. Both of them give a crimson flame due to the element strontium and after intense ignition give an alkaline reaction when placed on moistened tumeric paper. Celestite fuses readily and when heated with sodium carbonate and a reducing agent like charcoal produces a dark stain of silver sulphide when placed on a piece of moistened silver, thus indicating the presence of the sulphate radicle in the compound. Strontianite effervesces when treated with dilute hydrochloric acid, thus indicating the presence of carbonic acid.

\section{USES OF STRONTIUM.}

The metal strontium is not commercially used so far as the writer is aware, but its salts are variously employed. Of these the hydrate and nitrate are of greatest importance. Different textbooks and dictionaries on industrial chemistry give different methods whereby the hydrate is made from the sulphate. In general, however, the principles involved are the reduction of the sulphate to the sulphide either by charcoal or coal, the extraction of the sulphide with water, and the subsequent precipitation of the hydrate by a metallic oxide or hydrate. A very simple process for obtaining the hydrate is the calcination of the carbonate, strontianite, where it is available. The temperature required is much higher than that of ordinary lime burning.

Strontium hydrate is used principally in the recovery of sugar from beet molasses. The process is still employed in Germany and by the Raffinerie Parisienne, but the cost of the hydrate is too great for its use to become general. Strontium sucrate (saccharate) is much more easily formed than calcium sucrate, and for this reason the celebrated German chemist, Carl Scheibler, of Berlin, has urged the use of strontium hydrate in sugar factories, especially as Germany has extensive deposits of strontium minerals from which it has been possible heretofore to obtain the hydrate cheaply. The beet molasses is mixed in suitable proportions with the hydrate and the sucrate is formed. The mother liquors are separated by filter presses. The cakes of strontium sucrate are washed, then mixed with water, and carbonated. The strontium carbonate thus formed is burned to the caustic condition and used over again.

Strontium nitrate is made by dissolving the carbonate in nitric acid, if the native mineral can be procured sufficiently free from other bases that would consume the acid. The carbonate used is some- 
times made from the sulphate by fusing it with soda ash and leaching out the sodium sulphate formed by the double decomposition: $\mathrm{SrSO}_{4}+\mathrm{Na}_{2} \mathrm{CO}_{3}=\mathrm{SrCO}_{3}+\mathrm{Na}_{2} \mathrm{SO}_{4}$. The chief use of strontium nitrate is in pyrotechny, where it imparts a red color to the flame. The chlorate and carbonate are also used for this purpose but to a less extent.

Strontium in the form of the iodide, bromide, acetate, lactate, arsenate, phosphate, and other salts is used as medicine and in the chemical laboratory.

\section{VALUE OF STRONTIUM MINERALS.}

Celestite can hardly be assigned a value in the United States, because heretofore it has not been found in sufficient quantities and in positions accessible enough to make its exploitation profitable, in view of the scant demand for it. At the present time, therefore, it may be considered to have only a potential value. When attention is drawn to important deposits very likely uses will be developed for it. The uses already discovered, as indicated above, and the fact that it is manufactured in Europe into chemicals that are imported into the United States suggest that the time may come when the more extensive deposits in this country may be worked.

\section{DEPOSITS OF STRONTIUM MINERALS.}

Mode of occurrence.-The metal strontium is intermediate in the periodic system between calcium and barium. It is found in small amount in the igneous rocks, an average of 611 analyses showing its presence to the extent of 0.04 per cent in the form of its oxide (SrO), and to the extent of 0.033 per cent in elementary form. It can be detected in sea water by ordinary methods. It is also found in the ashes of sea weeds and in boiler scale.

Strontium and calcium are chemically so closely related that their common association in rocks is to be expected. In any natural sequence of chemically deposited sediments the solubility of strontium sulphate places it above a calcareous deposit $\left(\mathrm{CaCO}_{3}\right)$ and below calcium sulphate (gypsum). It follows, therefore, that celestite may be dissolved away from lime and redeposited to form secondary masses. It also follows that its common association with gypsum and calcareous sediments in general is to be expected.

Celestite is usually associated with limestone or sandstone. It may also occur in beds of gypsum, salt, or clay. Locally it is associated with metalliferous ores, as with galena and sphalerite. In places it fills the cavities in fossils and in certain volcanic regions it is associated with sulphur.

New York.-In the United States celestite is much commoner than strontianite. In a few places the two minerals are known to occur 
together. In the vicinity of Schoharie, Schoharie County, N. Y., the minerals have been found in a rather impure limestone. They occur in pockets and thin seams and have been found in greatest quantity on the east side of Schoharie River, near quarries in limestone of the Helderberg group. The combination of strontium minerals is known to extend for about a mile west of the river, but their extent east of the river is unknown, as no openings have been made in the limestone in this direction.

Strontianite occurs in rocks of the Clinton formation near Clinton, Oneida County, N. Y., associated with celestite in geodes. The carbonate forms the outer part of the geode, inclosing the sulphate. ${ }^{1}$ The nodules and geodes are found in limestone and sandstone beds and also in the oolitic iron ore beds of the vicinity. The best examples of the occurrences were found at the old quarries near Lairdsville, 2 miles west of Hamilton College. ${ }^{2}$

Celestite and strontianite have also been found near Theresa and on the shore of Chaumont Bay, in Jefferson County, N. Y.

In the town of Adams, about 2 miles from the village of Adams Center, in Jefferson County, a vein of celestite is known to occur in the Trenton limestone. An occurrence has also been reported near Lockport, Niagara County. E. H. Kraus ${ }^{3}$ has reported celestite as disseminated through dolomitic limestone near Syracuse. Other places in New York where celestite is said to occur are at the Rossie lead mine and Stark, in St. Lawrence County, and at Depauville, in Jefferson County.

Ohio.- One of the most noted localities in the United States where strontium minerals have been found is Put-in-Bay, South Bass Island, Ottawa County, Ohio. Here celestite was found in 1897 during the sinking of a well, the walls of which caved in, revealing a cavern in limestone. The floor, ceiling, and walls of the cave were found to be composed of celestite, and the owner reported that the mineral was found to a depth of 22 feet below the floor. Traces of strontia were found in the vicinity. Of the 150 tons of celestite removed, 40 tons was exported to Germany.

Texas. ${ }^{4}$ - In 1904 a deposit of celestite was developed 5 miles north and a little west of Austin, Tex., in the Mount Bonnell and Mount Barker district. The celestite is associated with strontianite, Epsom salts, and other minerals and occurs in a flat-lying arenaceous and argillaceous magnesian limestone bed in the Glen Rose limestone (Lower Cretaceous). The limestones are soft, are of a rich cream or yellow.

1 Am. Jour. Sci., 2d ser., vol. 13, 1852, p. 264.

2 Idem, 3d ser., vol. 33, 1887, p. 286.

${ }^{3}$ Idem, 4 th ser., vol. 18, 1904, p. 30.

4 First Rept. Geol. Survey Texas, 1889, p. 125. Third Rept. Geol. Survey Texas, 1891, p. 229. Hill, R. T., Twenty-first Ann. Rept. U. S. Geol. Survey, pt. 7, 1901, pp. 144-147. Hess, F. L., Eng. and Min. Jour., vol. 88, July 17, 1909, p. 117. 
color, and alternate with softer marls of similar composition, containing pockets or nodules composed of calcite, aragonite, strontianite, and celestite. From measurements made on photographs Hess estimates that there is not more than 5 per cent of celestite in the richest exposures observed.

The celestite has been found in cleavable masses of irregular shapes, varying in weight from half a pound to 100 pounds. In developing the deposits it has been necessary to blast the rock, although it is rather soft. The deeper the work has extended into the hill (about 50 feet below the summit of Mount Bonnell) the purer and more abundant was the celestite obtained. Its color varied from white to pale bluish gray.

Samples analyzed by Ledoux \& Co., of New York City, after drying at $212^{\circ} \mathrm{F}$., showed 97.64 per cent of $\mathrm{SrSO}_{4}$, and tests made in the laboratory of the University of Texas showed the samples to be 98 per cent pure. In 1904 a carload of the ore was mined and shipped to Germany, but money was lost by the transaction.

West Virginia.-An occurrence of celestite has been noted near Cedar Cliff, Mineral County, W. Va., and an account of the crystals found there has been given by G. H. Williams. ${ }^{1}$ The rock in which the celestite crystals occur is a thickly bedded, nearly horizontal argillaceous limestone, similar to that used in the neighboring cities in Maryland in the manufacture of cement. The celestite occurs in crystalline form in flattened lenticular cavities or pockets from a foot to a yard in diameter and from 3 to 7 inches in height. The cavities apparently represent foreign concretions. In the adjacent limestone strontium sulphate was found so abundantly as to indicate that the rock was strongly impregnated.

Other occurrences in the United States.-Celestite is known to occur at Drummond, Chippewa County, Mich. In Monroe County of the same State, according to E. H. Kraus and W. F. Hunt, ${ }^{2}$ it is found. disseminated through dolomite, and at the point especially studied the upper layer of the rock contained over 14 per cent of celestite. Below this layer there is a porous stratum with cavities containing celestite and free sulphur. The latter is found in considerable quantities and was probably formed by reduction of the sulphate.

Celestite has also been found near Frankstown, Blair County, Pa.; in Brown County, northeastern Kansas; in Larimer County, Colo.; in cavities in limestone near Nashville, Tenn.; and associated in fine clear crystals with the colemanite of Death Valley, San Bernardino County, Cal.

Strontianite occurs with celestite in New York, as already noted, and is also found in Mifflin County, $\mathrm{Pa}$. 
Foreign occurrences.-Nearly all the strontium salts used in the United States are imported from Germany. The German manufacturers obtain their raw material in part near Hamm and Munster, Westphalia, where considerable quantities of strontianite are found, and from Thuringia, both States in the western part of the German Empire; also from Sicily, where celestite occurs in abundance. The presence of extensive deposits of strontium minerals at places where they may be mined cheaply is one of the reasons why the salts derived from them are used so extensively in Germany. Other reasons are outlined in the section on uses. For information concerning other foreign occurrences of strontium minerals, of which there are many, the reader is referred to the works of Dana, ${ }^{1}$ Clarke, ${ }^{2}$ and others.

\section{CELESTITE IN CALIFORNIA.}

Location.-Celestite, together with salt, gypsum, and other important economic minerals, occurs along the northeast margin of the Avawatz Mountains, in San Bernardino County, Cal. The minerals are located on land of the Avawatz Salt \& Gypsum Co., which has 52 claims containing about 5,200 acres. These clajms are located near and tied by survey to Government monuments at the south eighth corner west, sec. 15 , original quarter corner between secs. 22 and 23 and original quarter corner between secs. 25 and 26, T. 18 N., R. 5 E. San Bernardino meridian. They lie in a belt 9 miles long by $1 \frac{1}{2}$ miles wide in spur ridges along the northeast margin of the Avawatz Mountains, near the south end of Death Valley. The nearest railroad is the Tonopah \& Tidewater, about 10 miles east of the southeast end of the claims. Figure 55 gives the general location of the claims with reference to well-known points in southern California.

Topography.-The spur ridges on which the properties are located are trenched by the drainage channels of the mountains and indented by alluvial fans composed of material similar to that found in the valleys north of the deposits. This material is the wash brought down from the mountains. The country slopes off gradually from the edge of the hills, where the gradient is steep, to the center of the valley, where it is very gentle and renders railway or highway construction comparatively easy, so far as the topography is concerned. In general it may be said that the details of the topography are rough. (See fig. 56.)

Geology.-There are three general divisions of the rocks which are of economic importance. These are (1) a basement complex of stratified rocks which have been metamorphosed and intruded by igneous rocks; (2) lake beds containing salt, gypsum, and celestite; and (3) gravels concealing the older beds.

1 Dana, J. D., System of mineralogy, 6th ed., 1909, p. 905.

${ }^{2}$ Clarke, F. W., The data of geochemistry, 2 d ed.: Bull. U. S. Geol. Survey No. 491, 1911, pp. 552-553. 


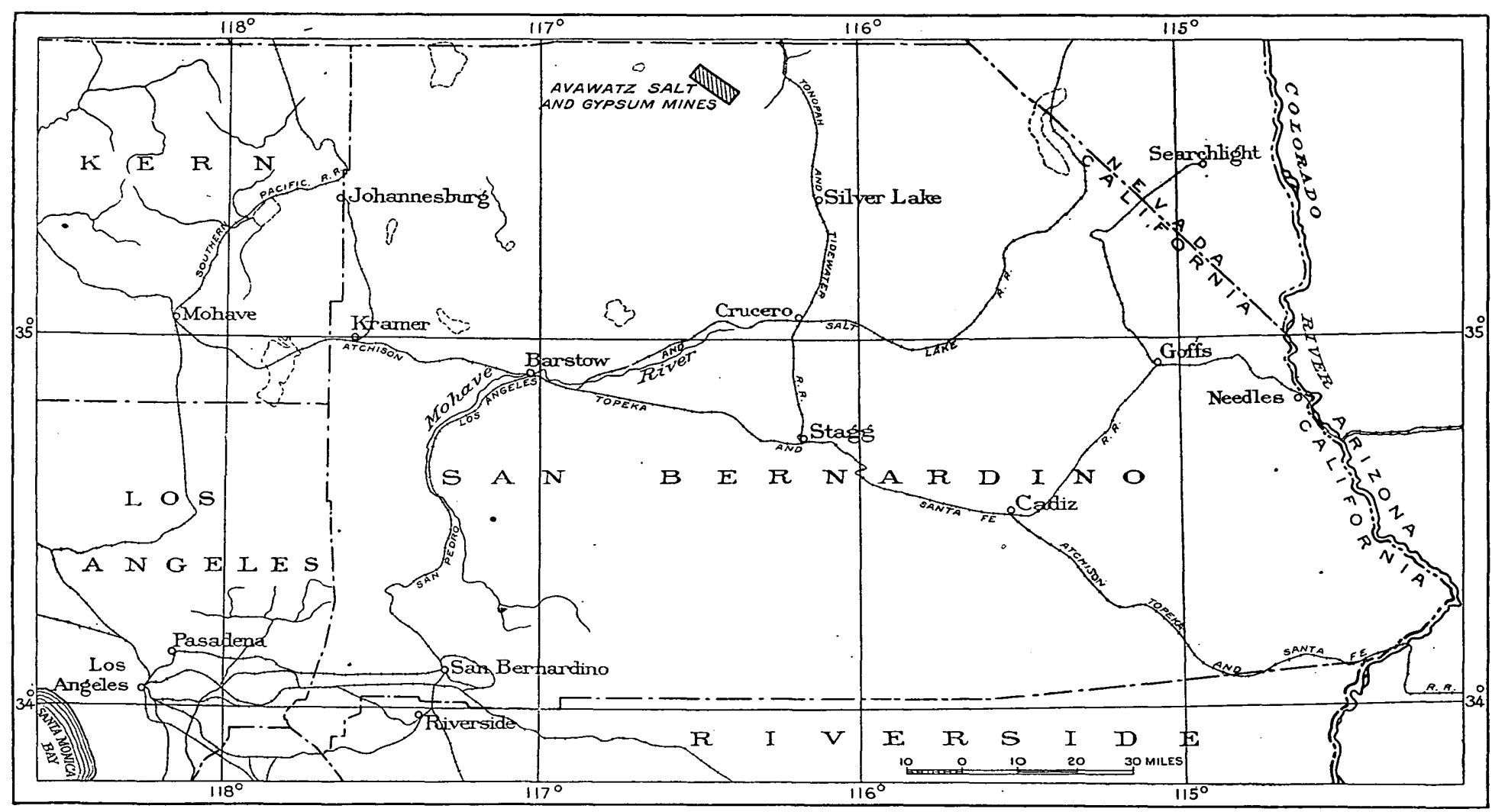

FiguRe 55.-Key map showing location of claims of Avawatz Salt \& Gypsum Co., San Bernardino County, Cal. 
The lake beds are separable into five main divisions-the basal series of lake beds, the celestite beds, the gypsum series, the salt series, and the upper series of lake beds.

The basal or lower lake beds are made up of conglomerates, sandstones, shales, and soft clays, the whole having in general bright colors. They may thin or be entirely absent in places. Detailed work may develop the fact that there are two distinct series in these lower lake beds, possibly separated by an uncomformity. This suggestion is based on differences in degree of consolidation, in. coloring, etc. These lower lake beds contain in some places gypsum and beds of

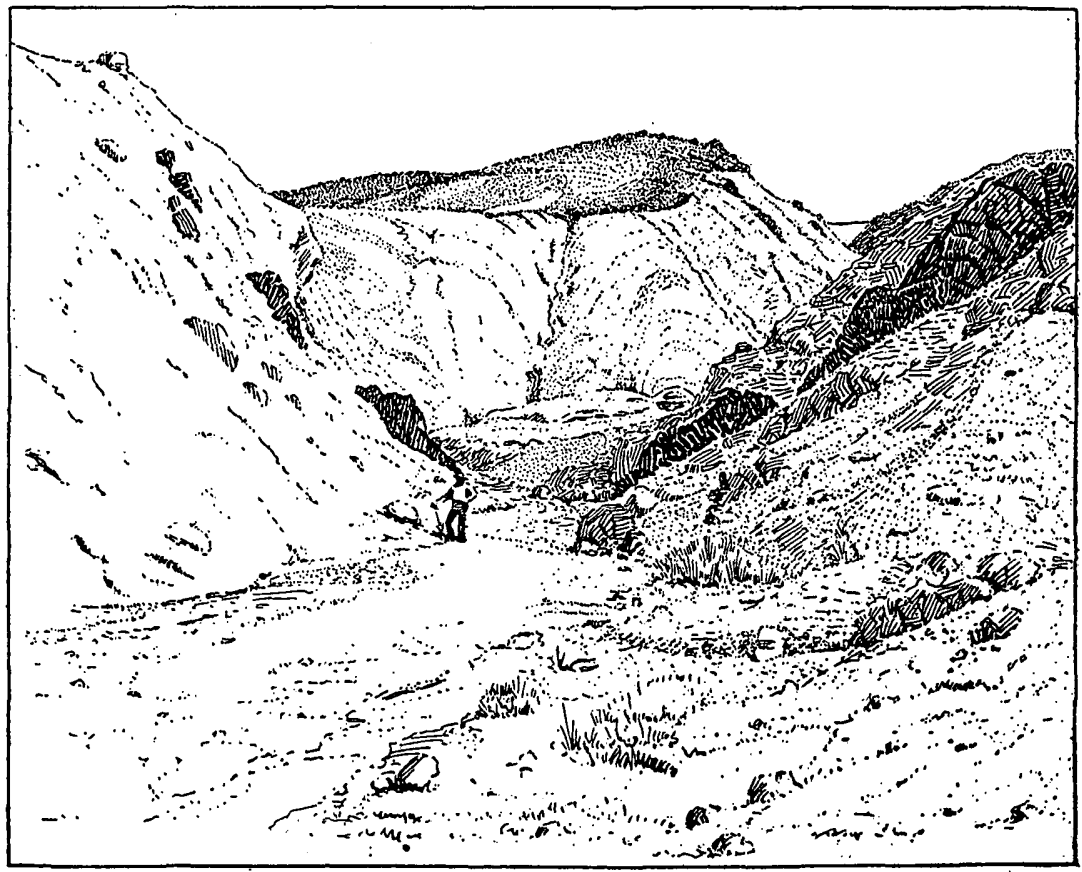

FIGURE 56.-Outcrop of bedded celestite deposit (dark ledges) in Avawatz Mountains, San Bernardino County, Cal. Sketched from photograph.

celestite atvarious horizons. The thickness varies from place to place, being abnormal where there is much repetition by faulting.

Above the lower lake beds and below the gypsum occur the celestite beds, which were observed in general from the middle of the claims to their west end. The principal outcrops observed were near and west of the Jumbo salt outcrop. The celestite is exposed in the form of resistant "hogbacks," in some places flanking the ridges and in others cutting them and continuing across the valleys between them.

The thickness of the celestite zone may be locally as much as 75 or 80 feet, but the exact thickness is difficult to ascertain in all places owing to the presence of wash and talus. East of Cave Springs Wash 
the outcropping reef or band of celestite was paced and found to be about 75 feet thick. It must not be understood that the entire thickness of the outcropping reef is pure celestite. It is more than probable that the pure mineral will be found in some places in thin bands and streaks and in others more or less intimately mixed with other substances, for example, gypsum, quartz in the form of sand or chalcedony, clay, and the oxides of manganese, iron, etc.

Careful prospecting and sampling will be necessary before the deposits are worked to determine accurately where the purest material occurs.in the largest amount and in the best position for exploitation. It is to be expected that some of the material in the celestite zone will prove to be of low grade.

There is no sharp dividing line between the lower series of lake beds and the overlying celestite and gypsum beds, the different series merging into one another gradually. There is also no sharp division between the gypsum and the overlying salt beds, or, in the absence of the salt series, between the gypsum and the overlying shales and clays. In a series of chemically deposited sediments this is to be expected. The division made above, however, is convenient for descriptive purposes.

In the stratigraphic sequence the salt overlies the gypsum beds. As a rule it is massive and does not show crystalline structure. Its color is usually reddish or brown, the discoloration being due to small amounts of iron oxide or colored clay. In general the line of separation between the salt and the underlying gypsum can be readily made out where exposures are good. The exposures of the gypsum are a as a rule light colored; those of the salt are dull or reddish brown from the residual clay left from the solution of the salt. Toward the base of the salt series occur saline clays and sands with some dolomite or gypsum, followed in upward sequence by the main salt beds, which are in turn overlain by saline clays and sands that merge with the overlying lake beds. The arid climate accounts for the appearance in places of massive salt outcrops practically at the surface. In places the salt is not present where the stratigraphic sequence indicates that it would be natural to expect it. Its absence may be accounted for on several hypotheses, such as nondeposition, solution, or faulting.

The upper lake beds overlie the salt and consist chiefly of gravels, clays, and sands, with local thin saline beds and small quantities of gypsum. It is possible that in places these beds may be or include the stratigraphic equivalent of the salt beds.

In a general way the strike of the beds follows the north edge of the Avawatz Mountains, curving to the northwest, as indicated in figure 55 . Earth movements have been intense in the region, and the rocks show faulting and folding on both a large and a small scale. The general $22652^{\circ}-$ Bull. $540-14-34$ 
trend of the folds is to the northwest. There is a finely developed fold in the lake beds near the mouth of Denning Spring Wash, not far from the west end of the deposits. The faulting and folding have resulted in steep dips and many of the beds stand nearly on edge. Figure 56, sketched from a photograph, illustrates this feature and gives a better idea of the "hogback" nature of the outcrop of the resistant celestite than could be obtained from a text description.

Physical character.-The typically exposed reefs of celestite are dark brown in color and are conspicuous beside the light-colored gypsum. This dark-brown color may be due to the presence of manganese or iron oxides, or both, but in general it is more suggestive of the former than of the latter. Not all the celestite is dark brown; a great deal of it is of light color, and the deep color is more characteristic of the exposed than of the freshly fractured mineral. In texture it varies from compact to coarsely crystalline. The crystalline nature of most of the mineral collected is apparent in hand specimens. Its high specific gravity is a help in identifying it in the absence of other heavy nonmetallic minerals, of which barite is an example.

- Chemical character.-In its pure form celestite or strontium sulphate contains 56.4 per cent of strontium oxide ( $\mathrm{SrO}$ ) and 43.6 per cent of sulphur trioxide, or sulphuric anhydride $\left(\mathrm{SO}_{3}\right)$. These figures will help in indicating the purity of the samples whose analyses are given below and on page 533 .

Analyses of celestite from Avawatz Mountains, Cal.

\begin{tabular}{|c|c|c|c|}
\hline & 1 & 2 & 3 \\
\hline 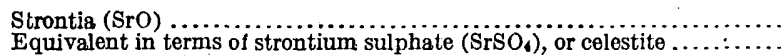 & $\begin{array}{l}50.99 \\
90.42\end{array}$ & $\begin{array}{l}38.41 \\
68.11\end{array}$ & $\begin{array}{l}40 \\
84.98\end{array}$ \\
\hline
\end{tabular}

1. R. A. Perez, Los Angeles, Cal., analyst. . Analysis furnished by Avawatz Salt \& Gypsum Co. The entire analysis as reported by Perez is as follows:

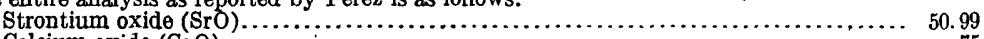

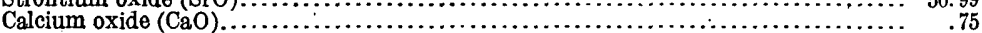

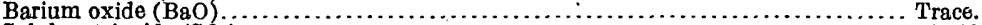

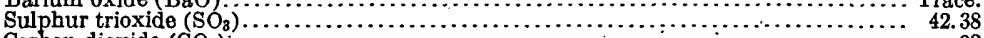

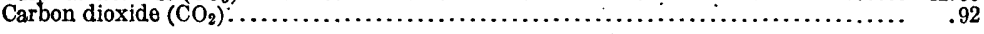

95.04

Gold, trace; silver, trace. Siliceous material, moisture, water of crystallization, etc., not determined.

2, 3. Samples collected near the west end of the property by W. C. Phalen. Analyses made in the laboratory of the United States Geological Survey by W. C. Wheeler.

Qualitative tests made on samples 2 and 3 showed the presence of ferric oxide and alumina. Manganese, lime, and barium were found in all the samples, as was also carbon dioxide. The amount of sulphur trioxide in each sample selected for quantitative analysis was larger than was required by the strontium present, which is believed to be wholly in the form of the sulphate. The excess of sulphur trioxide is probably present chiefly as sulphate of calcium, probably in the form of gypsum. The small amount of barium 
present is also probably in the form of the sulphate. The carbon dioxide is mostly present in carbonate of calcium.

The specimens were selected with no special attempt to procure the richest material, but simply with the idea of taking representative material of good grade. The content in strontium sulphate in the material thus selected is noteworthy.

\section{CELESTITE IN ARIZONA.}

Location.-Celestite occurs 15 miles south of Gila Bend, Maricopa County, Ariz., on unsurveyed land, so far as can be told from the State map issued by the General Land Office. The claims which cover the occurrence are known as the Montezuma claims Nos. 1, 2, 3,4 , and 5 , and are under location by W. D. Conrad and Lambert

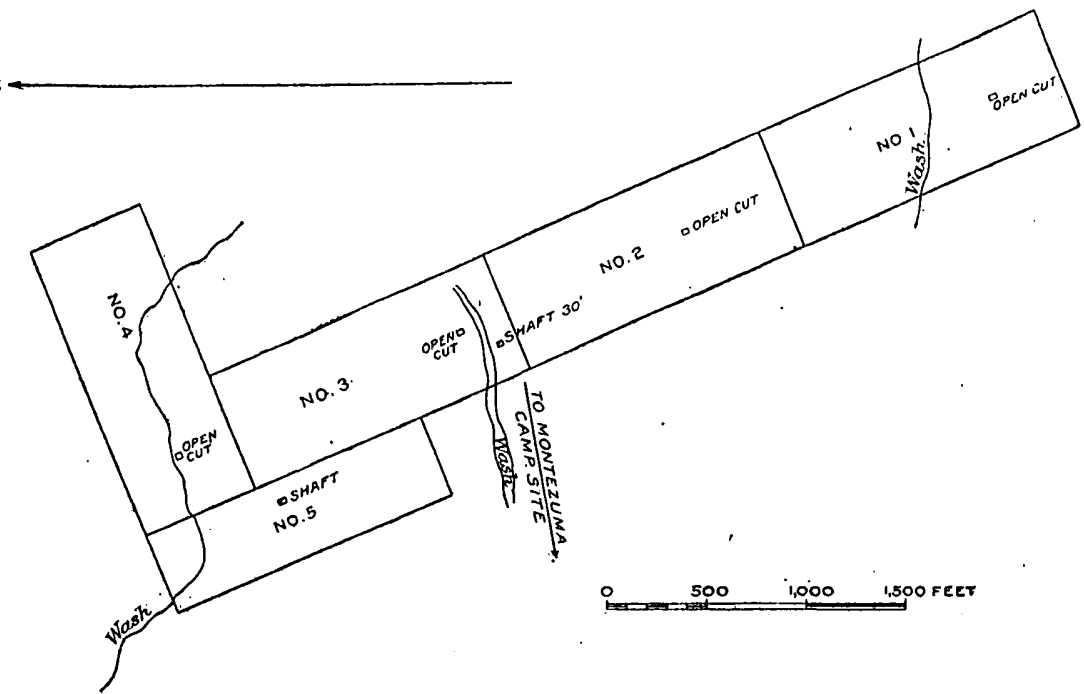

FiguRe 57.-Sketch map of Montezuma mining claims, 15 miles south of Gila Bend, Ariz.

Frye, of Gila Bend. The southeast end of the claims is a short distance S. $80^{\circ}$ E. from Montezuma, a well-known camp site for travelers going into the country south of Gila River. (See fig. 57.)

General relations.-The deposits are located well down on the side of a ridge that forms part of a somewhat isolated group of hills, such as are characteristic of this general region. Toward the west there is a broad expanse of level land, a mesa or old lake valley, slightly dissected by "dry washes," through which water runs at certain seasons of the year or after severe rains.

The main mass of the hills in which the sedimentary deposits occur and the surrounding hills to the northeast and east are made up of basalt, of the compact, vesicular, and porphyritic varieties. A basalt dike about 20 feet in thickness cuts across the sedimentary 
series in an east-west direction at the south end of the claims and forks east of the deposits. Toward the northwest end the sandstone underlying the celestite bed proper is underlain by porphyritic basalt striking N. $40^{\circ} \mathrm{W}$., in substantially the same direction as the sedimentary beds with which it is associated.

Occurrence.-The celestite occurs in a sedimentary series associated with gypsum, sandstones, and conglomerates containing pebbles of coarse-grained granite. The series is involved with igneous flows and intrusions. At the south end of the deposits the strike is N. $5^{\circ}-20^{\circ} \mathrm{E}$. and the dips are high, ranging from $45^{\circ}$ to $70^{\circ} \mathrm{E}$. Toward the north the beds swerve to the northwestward slightly, and the strike becomes N. $10^{\circ}-28^{\circ} \mathrm{W}$., with lower dips ranging from $15^{\circ}$ to $35^{\circ} \mathrm{E}$. The deposit is easily traced at the northwest end of the claims and may be observed extending a short distance beyond the base of the hills on the mesa proper, where it disappears beneath sands and gravels. Between the northwest end and the southeast end the deposit of celestite is hidden in places by the excessive amount of wash and talus resulting from the disintegration of the basalt in the ridge above. The length of the deposit observed is approximately 1 mile.

The celestite occurs in the form of a bed or beds overlain and underlain in some places by sandstone beds and in others by igneous flows. In the northwestern part of the deposit, where the relations and thicknesses can be best determined, the bed with which the celestite is directly associated is 40 to 50 feet thick. Of this thickness the upper 8 to 10 feet looked most promising as a source of the mineral, as judged from natural outcrops and small prospects, the remainder of the celestite zone appearing rather sandy. Careful prospecting will be necessary to determine the thickness and extent of the purer layers of the mineral, which will without doubt be found in thin beds. In places in the northwestern part of the deposit the celestite is intermixed with gypsum, as well as sandstone. Gypsum was also noted in the southeastern part of the deposit. Toward the northwest the celestite appears to occur in two main layers.

The mineral presents a variety of appearances. The high density, of course, characterizes the purest material and enables it to be readily identified in the absence of similar minerals like barite. In general it is rather light colored, both on the outcrop and when freshly fractured. A pink phase in the northwestern part of the deposit was observed, the color probably being due to iron oxide. Some of the material observed is very dark, both where exposed naturally or where freshly fractured. The dark color is possibly due to the oxides of manganese. Sandy and clayey impurities are present. The macroscopic structure would ordinarily be described as massive and crystalline. The material is nearly all massive, but 
on the freshly fractured surfaces the presence of small crystals is readily made out.

Composition.-The following analyses show the chemical character of the celestite:

. Analyses of celestite from deposit south of Gila Bend, Ariz.

\begin{tabular}{|c|c|c|c|c|c|c|c|c|}
\hline & 1 & 2 & 3 & 4 & 5 & 6 & 7 & 8 \\
\hline 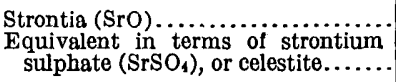 & 91.5 & 88.5 & 67.0 & 78.08 & 74.80 & 80.40 & 49.36 & $\begin{array}{l}48.99 \\
86.88\end{array}$ \\
\hline
\end{tabular}

1. From southwestern part of claim No. 3. Rex W. Dunlap \& Co., Phoenix, Ariz., analysts. Analysis furnished by W. D. Conrad.

2. From open cut on claim No. 2. Results are based on 100-pound sample sent to the California Drug \& Chemical Co. Los Angeles, Cai. Analysis furnished by W. D. Conrad.

3. From south end of claim No. 1. D. W. Rickhart, El Paso, Tex., analyst. Analysis furnished by W. D. Conrad.

4, 5, and 6: From claim No. 2, near open cut. Analyst not known. Analysis furnished by் W. D. Conrad.

7. From point near northwestem part of claims, upper part of bed. Collected by W.C. Phalen. Analysis made in laboratory of United States Geological Survey, by W. C. Wheeler.

8. Pink phase of celestite near northwest end of claims. Collected by W. C. Phalen. Analysis made in laboratory of United States Geological Survey, by W. C. Wheeler.

Qualitative tests of samples 7 and 8 showed the presence of ferric oxide and alumina, together with manganese, calcium, and barium. Carbon dioxide was present in sample 7 but absent in sample 8 . The sulphur trioxide in these two samples was found to be in excess of that required by the amount of strontium present, which, it is highly probable, is entirely in the form of the sulphate, celestite. The excess of the sulphur trioxide is probably partly in the form of sulphate of calcium, or gypsum, which occurs on the property, and also partly combined with the small amount of barium present. Calcium carbonate is undoubtedly present in sample 7 but absent in sample 8.

As with the California samples, the material taken from the deposit in Arizona was selected with a view to procuring representative material of good grade. The results given in analyses 7 and 8 are therefore worthy of consideration. 